\title{
Kajian hidrogeomorfologi pada DAS orde 0 (nol) di Dusun Brau Batu
}

\author{
Ferryati Masitoh*, Alfi Nur Rusydi**, Ilham Diki Pratama* \\ * Jurusan Geografi, Fakultas Ilmu Sosial, Universitas Negeri Malang \\ ** Jurusan Sistem Informasi, Fakultas Ilmu Komputer, Universitas Brawijaya
}

\begin{tabular}{l}
\hline \hline INFO ARTIKEL \\
\hline Riwayat Artikel: \\
Dikirim: $9-10-2018$ \\
Disetujui: 6-3-2019 \\
Diterbitkan: $30-6-2019$
\end{tabular}

\section{Kata kunci:}

Hidrogeomorfologi; DAS

Orde 0 (Nol); Mata air

\author{
Alamat Korespondensi: \\ Ferryati Masitoh
}

\begin{abstract}
This study aims to obtain an overview of hydrogeomorphological conditions in Zero Order Basin in Brau Village. Quantitative approaches are used by using primary and secondary data sources. Primary data includes: geomorphological, geological, and hydrological conditions. Secondary data used is Topographic Map data. The result of the study was in the form of a hydrogeomorphology of Zero Order Basin in Brau Village. Steep topography causes landslides, and water flows down gravitatively along the slope. The process of sedimentation occurs in a narrow depression zone located around seepage and springs. Tuffs and breccias (with cracks) cause high both porosity and permeability. Surface flow is not visible, but the baseflow occurs over the year. The baseflow that comes out as seepage and spring, is located in the bending area of the slope which has a narrow depression zone. The springs belt is formed at an elevation of 1,120-1,140 masl. The main function of Zero Order Basin in Brau Village is to accumulate water to form a complex river network system.
\end{abstract}

Abstrak: Penelitian ini bertujuan untuk mendapatkan gambaran kondisi hidrogeomorfologi pada DAS Orde 0 (Nol) di Dusun Brau. Pendekatan kuantitatif digunakan dengan sumber data primer dan sekunder. Data primer mencakup: kondisi geomorfologi, geologi, dan hidrologi. Data sekunder yang digunakan adalah data Peta Topografi. Hasil kajian berupa deskripsi hidrogeomorfologi DAS Orde 0 (Nol) di Dusun Brau. Topografi curam mengakibatkan terjadinya longsor dan air mengalir secara gravitatif menuruni lereng. Proses sedimentasi terjadi pada zona depresi sempit di sekitar rembesan dan mata air. Tuff dan breksi (dengan retakan) menyebabkan tingginya porositas dan permeabilitas. Aliran permukaan tidak nampak, tetapi aliran dasar terjadi sepanjang tahun. Aliran dasar yang keluar sebagai rembesan dan mata air, berada pada daerah tekuk lereng yang memiliki zona depresi yang sempit. Sabuk mata air terbentuk pada elevasi 1.120-1.140 mdpl. Fungsi utama DAS Orde 0 (Nol) di Dusun Brau yaitu untuk mengakumulasikan air sebelum terbentuknya sistem jaringan sungai yang lebih kompleks.

This is an open access article under the CC-BY-SA license.

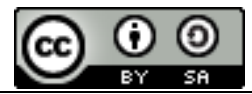


Jurnal Pendidikan Geografi:

Kajian, Teori, dan Praktik dalam Bidang Pendidikan dan Ilmu Geografi

Tahun 24, Nomor 2, Jun 2019, Hal 73-84

Jurusan Geografi

Fakultas Ilmu Sosial

Universitas Negeri Malang

Jalan Semarang 5, Kota Malang

E-mail: ferryati.masitoh.fis@um.ac.id

\section{PENDAHULUAN}

Air adalah salah satu kebutuhan utama bagi manusia. Sumber air yang dapat digunakan untuk memenuhi kebutuhan air antara lain: air tanah, air sungai, air hujan, dan air danau. Aliran air di atas permukaan tanah yang terjadi pada Daerah Aliran Sungai (DAS) memiliki beberapa kondisi. Triatmojo (2008) memberikan penjelasan bahwa aliran air di atas permukaan dapat berbentuk aliran air yang melalui parit, alur sungai, dan aliran air melalui sungai (stream). Aliran air di atas permukaan tanah akan terinfiltrasi membentuk air tanah, jika berada pada kondisi geomorfologi yang sesuai. Contoh kondisi geomorfologi yang sesuai yaitu kemiringan lereng dan kondisi batuan.

Daerah penelitian berada di Dusun Brau secara geologi merupakan Gunung Anjasmara Tua (Qpat) (Santosa \& Suwarti, 1992). Dusun Brau berada pada elevasi 1.090 $1.185 \mathrm{mdpl}$. Secara geomorfologi, dusun ini berupa lembah atau DAS kecil dengan beberapa mata air dan 2 (dua) sungai utama. Pembentukan mata air menjadi sumber utama air bagi penduduk setempat, terjadi akibat adanya variasi kondisi geomorfologi. Kemiringan lereng, kondisi morfologi, kondisi medan, kejadian gerak massa, dan proses pengendapan, adalah beberapa bukti adanya variasi geomorfologi di dusun ini. Pada proses perencanaan dan pengelolaan sumber daya mata air berkelanjutan, kajian hidrologi dan geomorfologi menjadi hal yang sangat penting. Kajian hidrologi dan geomorfologi sangat penting dilakukan untuk mendukung keberlanjutan mata air di Dusun Brau, sebab dusun ini merupakan salah satu tujuan wisata yang berkembang di Kota Batu, serta sebagai salah satu pusat peternakan sapi perah.

Pendekatan model matematis hidrologi umumnya digunakan untuk kajian hidrologi terutama berkaitan dengan DAS. Akan tetapi, model matematis hidrologi kurang dapat menggambarkan kondisi daerah sehingga akan memberikan kondisi hidrologi berbeda. Salah satu pendekatan yang dapat mengimbangi pendekatan matematis dari model hidrologi yaitu pendekatan geomorfologi. Sidle (2018), memberikan penjelasan tentang konsep DAS Orde 0 (Nol) yang menggabungkan kajian hidrologi dan geomorfologi. Pemahaman mengenai dinamika air, sedimen, dan nutrient, menjadi hal yang sangat penting dalam kajian DAS Orde 0 ( Nol). Letak DAS Orde 0 ( Nol) yang berada di daerah hulu memberikan gambaran mengenai kondisi daerah hulu dalam lingkup lebih sempit. Kontribusi DAS Orde 0 (Nol) yang lebih kompleks, lebih berkaitan dengan sistem jaringan sungai dan kondisi kelerengan. Sebelum adanya konsep DAS Orde 0 (Nol), Strahler telah mengemukakan mengenai sistem orde sungai. Perkembangan lebih lanjut mengenai sistem orde sungai yaitu DAS Orde 0 ( Nol) yang memungkinkan terbentuknya kajian. Konsep DAS Orde 0 (Nol) merupakan perkembangan lebih lanjut dari sistem orde sungai yang sebelumnya telah dikemukakan oleh Strahler. Secara khusus, penelitian ini hanya mengkaji interaksi antara hidrologi dan geomorfologi sebagai suatu kesatuan yang nantinya akan memengaruhi dinamika air pada DAS Orde 0 ( Nol), dan tidak mencakup analisis dinamika sedimen dan nutrien. DAS Orde 0 (Nol) merupakan bagian dari sistem DAS hulu yang difokuskan pada daerah dengan kelerengan curam dengan sistem hulu sungai berbeda dari sistem Strahler dan Horton. Sistem aliran air permukaan di DAS Orde 0 (Nol) tidak ada pada pada peta topografi, sebab bisa jadi tertutup oleh kanopi hutan. Akan tetapi, keberadaannya dapat diamati dari kondisi kelerengan curam (Benda, Hassan, Church, \& May, 2005). 
Jurnal Pendidikan Geografi:

Kajian, Teori, dan Praktik dalam Bidang Pendidikan dan Ilmu Geografi

Tahun 24, Nomor 2, Jun 2019, Hal 73-84

Menurut Hack \& Goodlett, (1960) dalam (Sidle, 2018) sistem DAS Orde 0 (Nol) memiliki 4 (empat) sub sistem topografi, yang antara lain: Nose, Side Slope, Hollow, dan Channel (lihat Gambar 1). Sistem DAS Orde 0 (Nol) masuk pada sistem hulu DAS terutama sebelum terbentuknya sistem sungai orde 1 (lihat Gambar 2). Grieve, et al (2018) dan Yamada (1999) memberikan penjelasan bahwa sistem yang memiliki topografi berupa puncak igir tertinggi disebut sebagai Nose. Puncak Nose tersebut akan membatasi sistem DAS Orde 0 (Nol) antara satu dengan lainnya. Lereng yang curam dan terletak pada sisi tepi Nose, disebut sebagai Side Slope. Kenampakan yang cembung akan terbentuk antara Nose dengan 2 (dua) Side Slope. Daerah yang berada di bagian tengah antara 2 (dua) Side Slope disebut sebagai Hollow. Hollow bukanlah berupa lubang dalam artian yang sebenarnya. Sistem Channel merupakan sistem aliran air permukaan yang airnya berasal dari Hollow. Berkaitan dengan sistem Channel yang dimasukkan ke dalam DAS Orde 0 (Nol) oleh Sidle (2018) dan Grieve, et al (2018), justru Yamada (1999) tidak memasukkannya ke sistem DAS-nya. Yamada (1999) memberikan alasan karena channel sudah merupakan bagian dari aliran permukaan. Grieve, et al (2018) menjelaskan bahwa pada bagian antara Hollow dengan Side Slope terdapat zone of convergence (lihat Gambar 3). Proses geomorfologi yang bersifat gravitasional pada awalnya akan mendominasi dalam sistem DAS Orde 0 ( Nol), kemudian dilanjutkan oleh proses hidrologi. Aliran bawah permukaan akan muncul jika hollow telah jenuh air, dan pada saaat musim hujan akan mampu membentuk aliran permukaan (Tsukamoto \& Hirohiko, 1987).

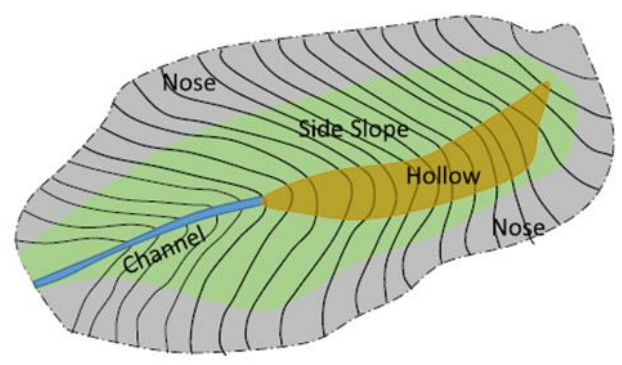

Gambar 1. Pembagian sistem topografi pada DAS Orde 0 (nol) menurut Hack \& Goodlett, (1960) dalam (Sidle, 2018)

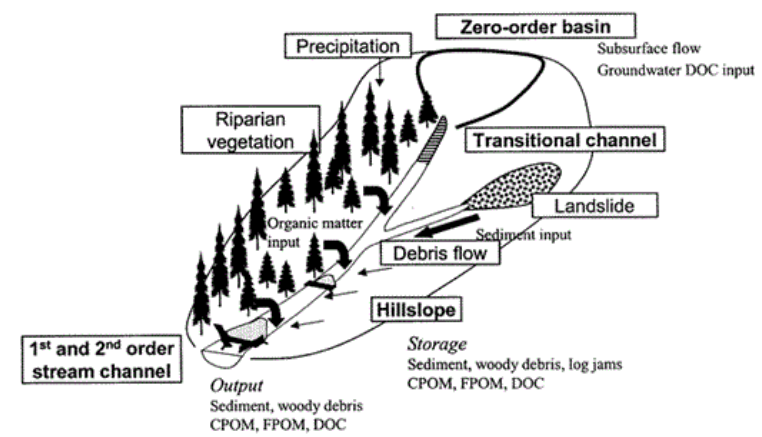

Gambar 2. Sistem DAS dengan DAS Orde 0 (Nol) pada bagian paling hulu DAS. (Gomi, Sidle, \& Richardson, 2002)

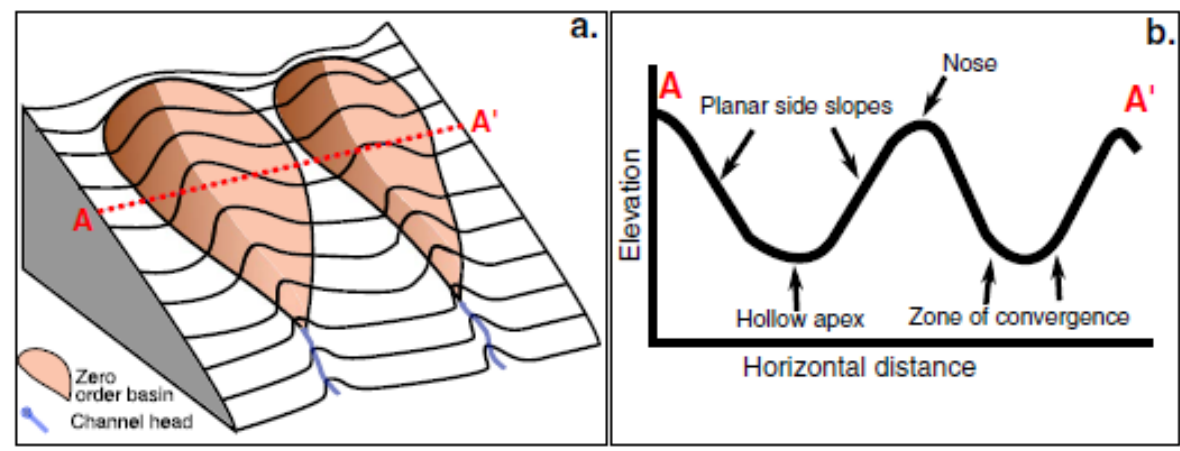

Gambar 3. Diagram Skematik DAS Orde 0 (Nol) (Grieve, Hales, Parker, Mudd, \& Clubb, 2018)

Terdapat 2 (dua) sungai utama di Dusun Brau yang berasal dari kelompok beberapa mata air dan rembesan. Jika dikaitkan dengan sistem orde menurut Strahler, maka keduanya termasuk dalam sistem sungai Orde 1 . Sungai ini memiliki mata air yang berasal dari mata air dan rembesan dari DAS Orde $0(\mathrm{Nol})$. Sistem sungai belum terbentuk pada DAS Orde 0 
(Nol), dan hanya berupa aliran dasar air tanah yang keluar sebagai mata air. Gambar 1 menunjukkan lokasi DAS Orde 0 yaitu pada wilayah A dan B yang berada di bagian selatan dusun. Wilayah A dan B merupakan kelompok mata air yang merupakan batas DAS Orde 0 (Nol).

Dusun Brau mempunyai luasan sangat kecil yaitu kurang dari $1 \mathrm{~km}^{2}$, berbentuk lembah (cekungan), serta mempunyai beberapa mata air, sehingga sesuai sebagai lokasi kajian hidrogeomorfologi DAS Orde 0 (Nol) (lihat Gambar 4). Secara geomorfologi, Dusun Brau berada pada satuan bentuk lahan lereng atas Gunung api Anjasmoro. Pada Gambar 4, nampak bahwa pada Dusun Brau terdapat kelompok mata air yang tersebar di bagian selatan dusun. Aliran air sungai berasal dari mata air dan rembesan yang mengalir kearah timur laut dusun. Verstappen (1983) memaparkan bahwa pada bentuk lahan vulkan memiliki proses dominan berupa pengangkutan oleh tenaga air dan secara gravitatif. Pembentukan lereng pada satuan betuk lahan vulkan terjadi secara bertahap yang materinya berasal dari endapan hasil erupsi gunung api. Variasi kemiringan lereng dari curam hingga agak curam terbentuk sebagai akibat adanya aktivitas pengangkutan oleh air dan kejadian longsor. Hasil observasi lapangan juga menunjukkan bahwa lembah-lembah sungai yang terbentuk di dusun ini adalah cukup dalam. Pada peta kontur yang ditunjukkan pada Gambar 4, nampak kontur rapat berada di sekeliling dusun (termasuk di daerah DAS Orde 0 (Nol), sedangkan daerah tengah (wilayah dusun) memiliki kontur relatif renggang. Peta kontur menunjukkan bahwa dusun berbentuk lembah dibatasi oleh igir-igir dengan lereng curam.

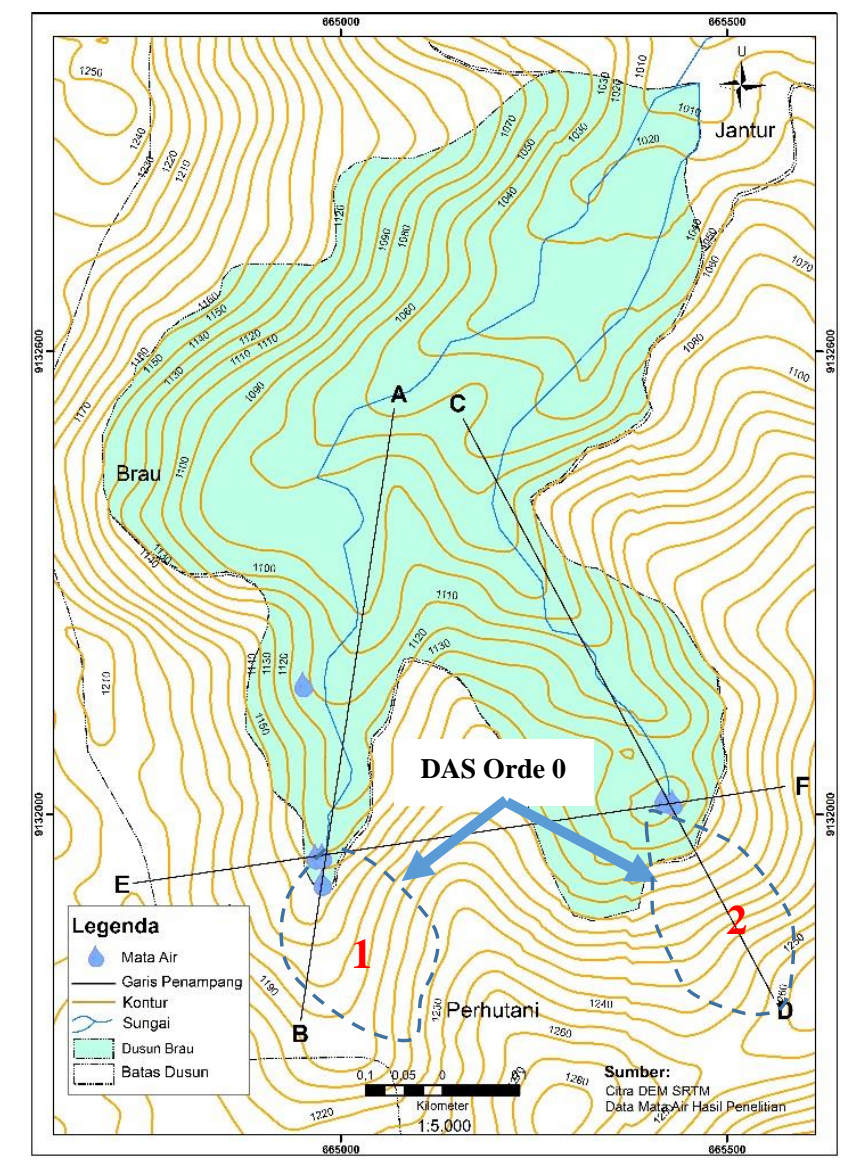

Gambar 4. Lokasi Kajian Hidrogeomorfologi DAS Orde 0 (Nol) Dusun Brau

Pada Gambar 4, juga terlihat adanya mata air. Terbentuknya mata air berkaitan dengan kondisi hidrologi air tanah. Verstappen (1983) menjelaskan bahwa hidrologi air 
Jurnal Pendidikan Geografi:

Kajian, Teori, dan Praktik dalam Bidang Pendidikan dan Ilmu Geografi

Tahun 24, Nomor 2, Jun 2019, Hal 73-84

tanah, dipengaruhi oleh iklim, geologi, betuk lahan, tanah, dan vegetasi dalam kondisi alami. Faktor bentuk lahan, sebagai bagian dari tinjauan geomorfologi, akan membantu dalam mengkaji litologi, struktur akuifer, serta materi pembentuk dan pengontrol hidrologi air tanah. Dalam penelitian ini, kajian hidrologi DAS Orde 0 (Nol) hanya mencakup aliran permukaan (Surface Run Off) dan aliran bawah permukaan (Sub Surface Run Off).

Bryan (1999) dalam (Todd, 1980) mengungkapkan bahwa mata air merupakan aliran air tanah yang keluar ke permukaan secara alamiah. Faktor iklim dan topografi akan memengaruhi keterdapatan mata air. Akan tetapi, faktor topografi memiliki peran terpenting untuk mengindikasi keterdapatan mata air dan air tanah. Daerah yang secara topografi berupa puncak igir serta lereng curam memiliki air tanah lebih sedikit jika dibandingkan dengan daerah berupa cekungan lembah dan bertopografi dataran. Sedikitnya air tanah pada daerah berlereng curam terjadi akibat besarnya erosi dibandingkan pelapukan batuannya. Proses pelapukan sangat penting untuk keterdapatan mata air dan air tanah, sebab akan membentuk zona atau lapisan permeabel. Pada daerah dengan kemiringan curam, kejadian erosi akan mengikis hasil pelapukan dan mengendapkannya di daerah lebih rendah. Hal ini mengakibatkan air tanah pada daerah berlereng curam tidak dapat terbentuk dalam jumlah banyak (De Wiest, 1966).

Bryan (1999) dalam (Todd, 1980) mengelompokkan proses terbentuknya mata air menjadi 2 (dua) jenis, yaitu mata air dari tenaga gravitasi dan non gravitasi. Air tanah yang mengalir di bawah tekanan hidrostatis akan membentuk mata air dari tenaga gravitasi. Mata air di daerah vulkan sebagai akibat dari proses retakan, rekahan, serta pecahan batuan pada kedalaman tertentu, akan membentuk mata air dari tenaga non gravitasi. Jika berasosiasi dengan akitivas geotermal, maka akan dapat membentuk mata air panas. Hendrayana (2015) memaparkan bahwa mata air akan terbentuk di daerah yang aliran air tanahnya terpotong oleh tekuk lereng (break of slope). Selain kondisi tekuk lereng, faktor retakan dan rekahan pada batuan juga menjadi hal penting. Retakan pada batuan yang padat dan kompak, dan atau rekahan pada zona permeabel, akan memberikan kemampuan meloloskan air tanah (permeabillitas) cukup baik. Hal ini akan menjadi faktor penting dalam pembentukan mata air secara alamiah.

Lokasi kajian berada di sisi selatan Dusun Brau Desa Gunungsari. Berdasarkan peta administratif, dusun ini berbatasan dengan wilayah Kelurahan Songgokerto, Kecamatan Bumiaji Kota Batu (lihat Gambar 4). DAS Orde 0 (Nol) berada pada bagian selatan dusun, yang ditandai dengan adanya 2 (dua) kelompok mata air pada elevasi $1.125-1.175$ mdpl. Titik lokasi kemunculan mata air, merupakan titik outlet dari sistem DAS Orde 0 (Nol). Jika ditinjau dari penggunaan lahan, maka lokasi kajian merupakan hutan dan kebun campur yang masuk dalam wilayah pengelolaan Perhutani.

\section{METODE}

Penelitian menggunakan pendekatan penelitian kualitatif dengan menggunakan dua parameter yaitu: Hidrologi dan Geomorfologi. Variabel dinamika panas, jenis aliran air dan sifat aliran air digunakan sebagai parameter Hidrologi. Karakteristik jenis batuan, struktur geologi, porositas dan permeabilitas batuan, kemiringan lereng, morfologi dan medan, gerak massa, dan aktivitas pengendapan digunakan sebagai parameter Geomorfo logi. Penelitian ini menggunakan Peta Geologi skala 1:100.000 lembar Malang untuk memberikan informasi berupa formasi geologi. Peta Topografi dibuat berdasarkan data SRTM, digunakan untuk mendukung analisis kondisi topografi daerah penelitian. Pemanfataan kedua data tersebut membantu dalam memberikan gambaran dan analisis kondisi morfologi daerah penelitian. Sebagai bagian dari Gunung Api Anjasmoro, daerah penelitian termasuk daerah yang mengalami proses denudasional intensif. Kegiatan survei lapangan dilakukan dengan 
memanfaatkan informasi geologi yang diperoleh dari data-data tersebut sebagai pedoman pelaksanaan di lapangan.

Kegiatan tahap berikutnya adalah survei lapangan. Parameter geomorfologi dan hidrologi diperoleh berdasarkan pelaksaanan kegiatan survei lapangan. Dalam kegiatan ini, observasi dan pengukuran kemiringan lereng dilakukan untuk memperoleh data variabel yang mencakup jenis batuan, struktur geologi, porositas dan permeabilitas batuan, kemiringan lereng, morfologi dan medan, gerak massa, dan aktivitas pengendapan. Observasi dilakukan pada pada aliran air permukaan dan aliran air bawah permukaan (air tanah) Pada sistem channel DAS Orde 0 (Nol) dilakukan pengukuran debit mata air. Kedua aktivitas ini ditujukan untuk memperoleh data tentang variabel dinamika panas, jenis aliran air dan sifat aliran air. Data yang diperoleh berdasarkan kegiatan lapangan selanjutnya dianalisis dengan pendekatan analisis deskriptif untuk mendukung penjelasan mengenai kondisi hidrogeomorfologi DAS Orde 0 (Nol) di Dusun Brau. Tahapan penelitian yang telah dipaparkan tersebut dirangkum dalam Gambar 5.

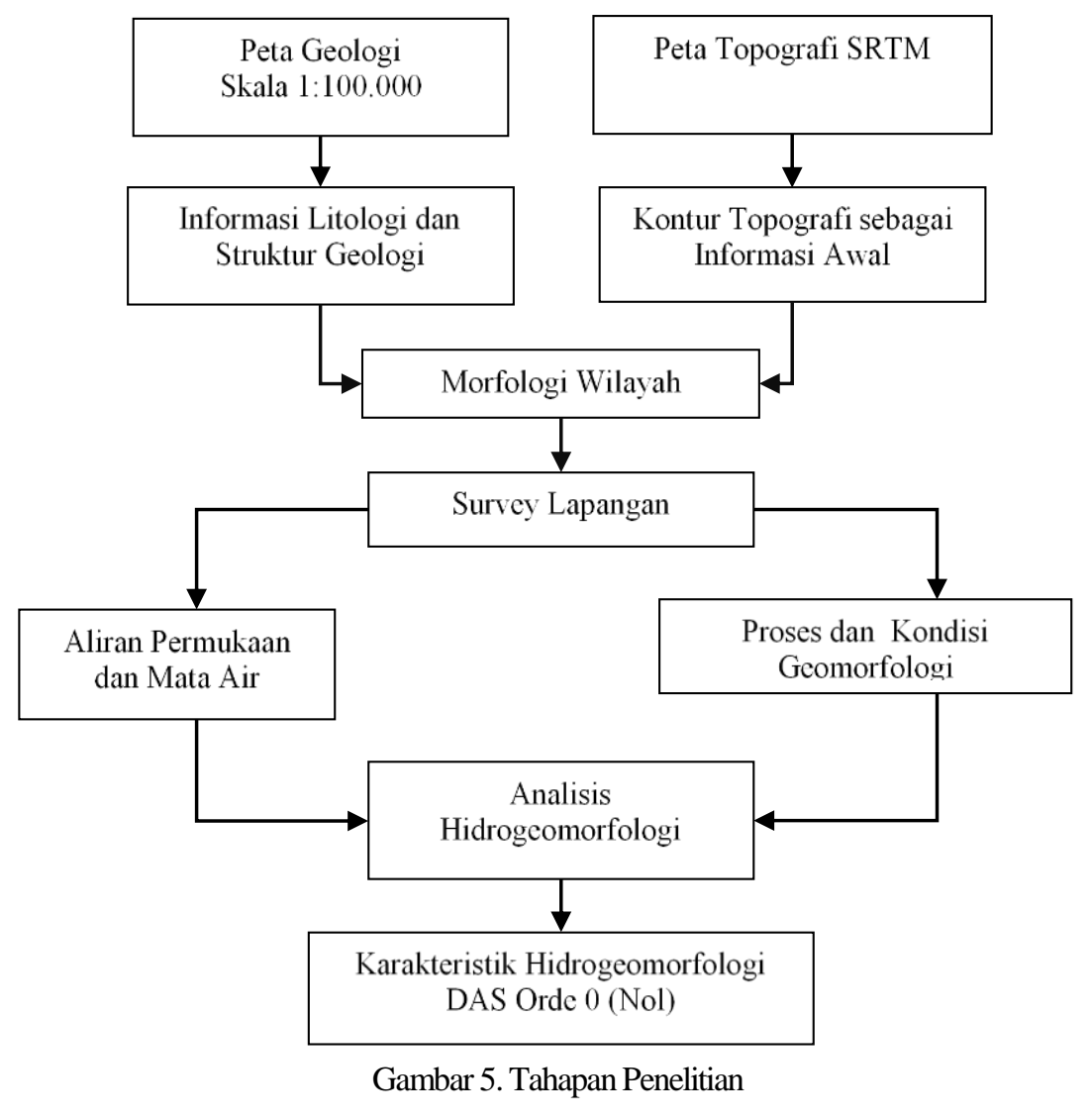

\section{HASIL DAN PEMBAHASAN}

Dusun Brau berada pada sistem Pegunungan Vulkan Anjasmoro. Secara geologi, dusun ini memiliki formasi geologi Qpat yaitu formasi Anjasmoro Tua. Informasi geologi yang diperoleh dari Peta Geologi skala 1:100.000 lembar Malang menyebutkan bahwa formasi Qpat terdiri atas tuff batu apung, tuff pasiran, tuff breksi, tuff halus dan tuff lapilli, breksi gunung api, dan lava. Formasi Qpat merupakan hasil dari aktivitas Gunung Api Anjasmoro Tua, memiliki perkiraan umur masa pembentukan yaitu pada Masa Kuarter Zaman Plistosen Awal hingga Tengah (Santosa \& Suwarti, 1992). Sebagai gunung api yang tidak aktif lagi, Gunung Api Anjasmoro telah mengalami proses perombakan intensif. Pada Gambar 6 dan 7 tampak singkapan batuan berupa tuff dan breksi dengan joint. Batuan tuff 
Jurnal Pendidikan Geografi:

Kajian, Teori, dan Praktik dalam Bidang Pendidikan dan Ilmu Geografi

Tahun 24, Nomor 2, Jun 2019, Hal 73-84

memiliki warna cerah kekuning coklatan, sedangkan batuan breksi vulkanik memiliki warna abu-abu gelap hingga kehitaman, dengan bentukan menyudut, kompak dan keras. Singkapan breksi vulkanik Gunung Api Anjasmoro mempunyai banyak joint, yang memudahkan terbentuknya aliran rembesan air tanah dan mata air di beberapa lokasi.

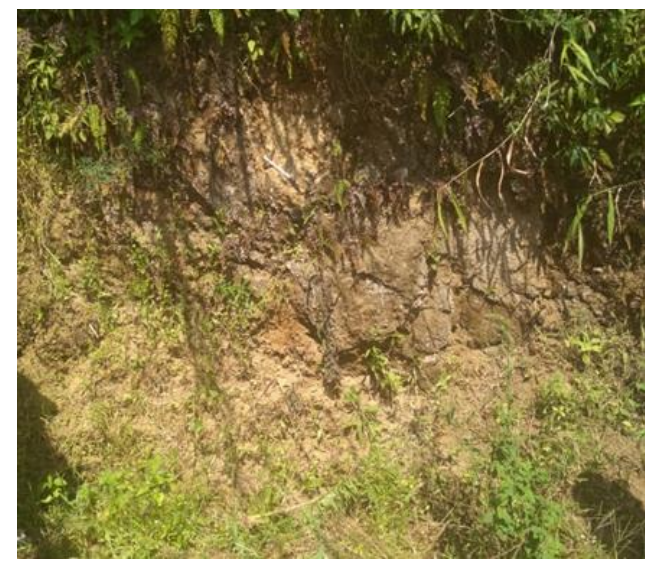

Gambar 6. Singkapan Tuff (koordinat: 665143 mT, $9132204 \mathrm{mU}, 1129 \mathrm{mdpal})$

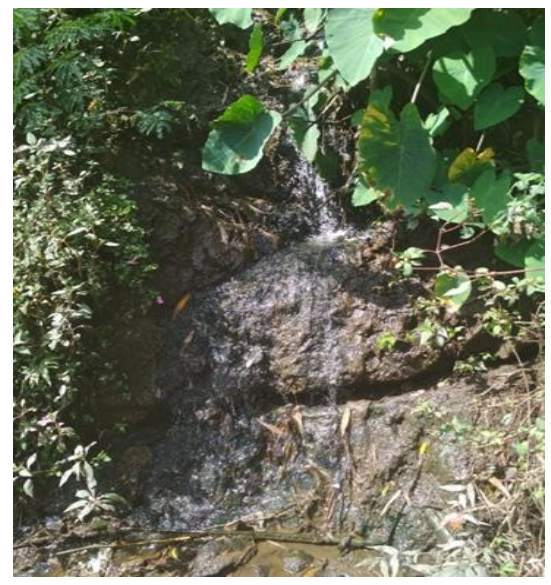

Gambar 7. Singkapan batuan breksi dengan joint (koordinat: $665403 \mathrm{mT}, 9131946 \mathrm{mU}, 1133 \mathrm{mdpal})$

Data SRTM memberikan informasi turunan mengenai kondisi topografi Dusun Brau yang memiliki bentuk seperti cekungan (concave). Di lapangan, dusun ini berupa lembah yang dibatasi oleh igir-igir yang tinggi. Elevasi igir di sisi timur hingga selatan dusun sekitar 1065 - 1285 mdpl, sedangkan pada igir sisi selatan hingga barat adalah 1078 - 1186 mdpl. Daerah yang memiliki elevasi paling rendah, dan bukan berupa igir, ada di bagian tengah ke utara dusun. Berdasarkan kondisi topografi tersebut, Dusun Brau terdiri atas puncak lereng, lereng atas, lereng tengah, lereng bawah, dan kaki lereng. Kondisi lereng memberikan pengaruh terhadap pergerakan air baik aliran permukaan, maupun aliran air tanah.

Penampang melintang DAS Orde 0 (Nol) Kelompok mata air 1 dan 2 ditunjukkan pada Gambar 8. Penampang melintang untuk segmen AB (kelompok mata air 1) ditunjukkan pada Gambar 8a, sedangkan penampang melintang untuk segmen CD (kelompok mata air 2) ditunjukkan pada Gambar 8b. Posisi segmen dari penampang melintang AB dan CD pada Dusun Brau, dapat dilihat pada Gambar 4. Gambar 8a dan 8b memperlihatkan kemiringan lereng yang curam hingga melebihi $45^{\circ}$ pada DAS Orde 0 (Nol). Proses gerak massa berupa longsor berlangsung intensif pada kemiringan lereng yang curam. Kejadin gerak massa akan semakin intensif pada saat musim hujan. Intensifnya kejadian longsor pada DAS Orde 0 (Nol) akan menyebabkan lapisan tanah mengalami penipisan tanah (Morse, Ning Lu, Godt, Revil, \& Coe, 2012). Vegetasi berkanopi dengan ketinggian sekitar 8 meter dari permukaan tanah menutupi puncak hingga lereng wilayah DAS Orde 0 (Nol). Aliran permukaan tidak nampak sebagai akibat kondisi daerah yang miring, tetapi aliran dasar bawah permukaan telah terbentu. Hal ini menjadikan DAS Orde 0 ( Nol) merupakan daerah yang baik sebagai daerah tengkapan air. Aliran dasar yang terbentuk di bawah permukaan, akan keluar sebagai rembesan dan rembesan. Pada elevasi antara 1.100 - 1.400 mdpl, terbentuk sabuk rembesan dan mata air. Sabuk mata air tersebut terletak pada daerah tekuk lereng (lihat Gambar 8a dan 8 b). Antara kelompok mata air 1 dan 2 terdapat igir yang memisahkan kedua DAS Orde 0 (Nol). Igir ini disebut sebagai Nose dengan elevasi tertinggi di $1.180 \mathrm{mdpl}$ (Gambar 8c). Grieve, et.al (2018) memberikan istilah zone of convergence untuk batas Side Slope dengan hollow. Zone of convergence merupakan lokasi akumulasi sedimen hasil proses gerak massa 
Jurnal Pendidikan Geografi:

Kajian, Teori, dan Praktik dalam Bidang Pendidikan dan Ilmu Geografi

Tahun 24, Nomor 2, Jun 2019, Hal 73-84

yang terjadi pada bagian Nose dan Side Slope. Sedimen yang berasal dari kedua sistem akan mengalami proses pengendapan pada hollow (Dietrich, et al., 1987; Sidle 2018).

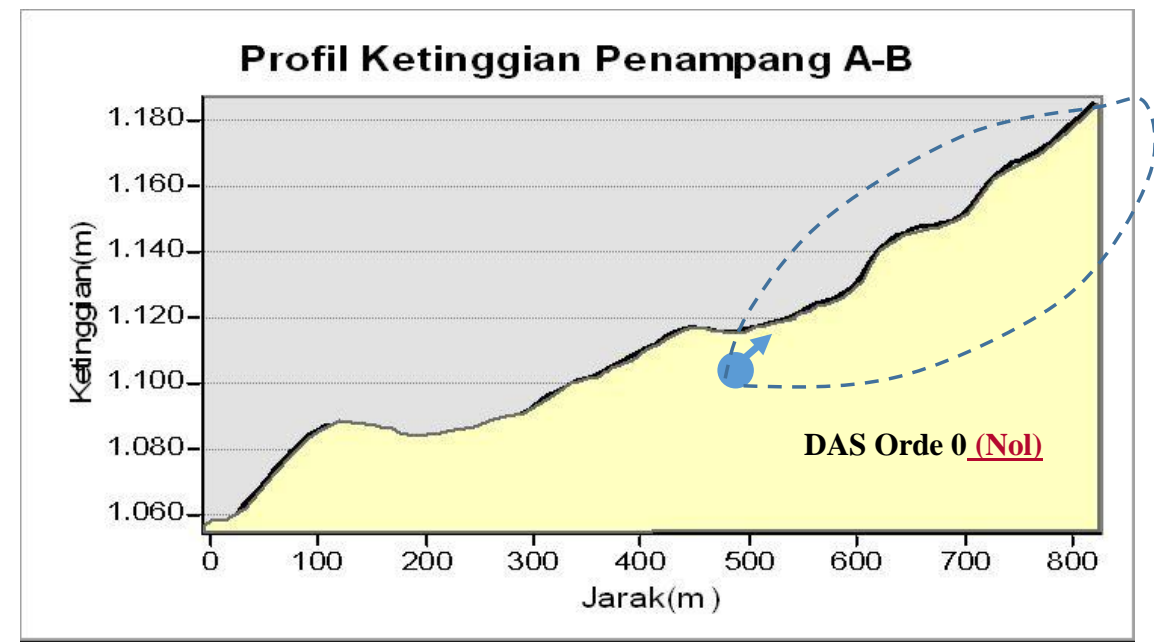

8a. Profil Ketinggian Penampang AB pada DAS Orde 0 (Nol) Kelompok Mata air 1

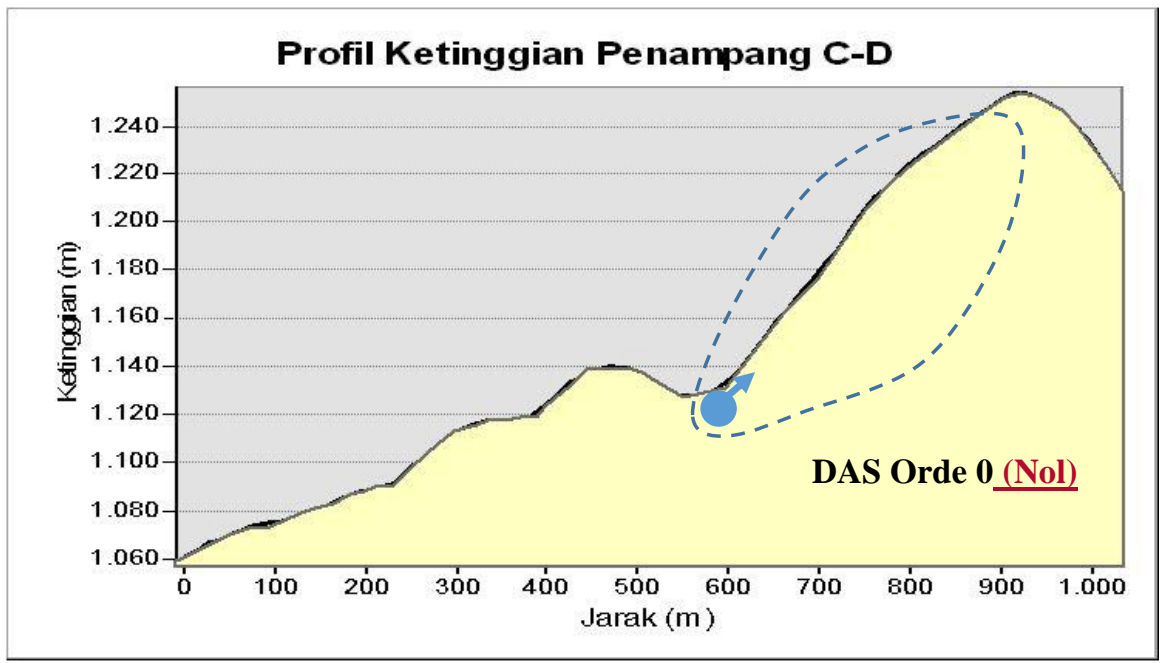

8b. Profil Ketinggian Penampang CD pada DAS Orde 0 (Nol) Kelompok Mata air 2

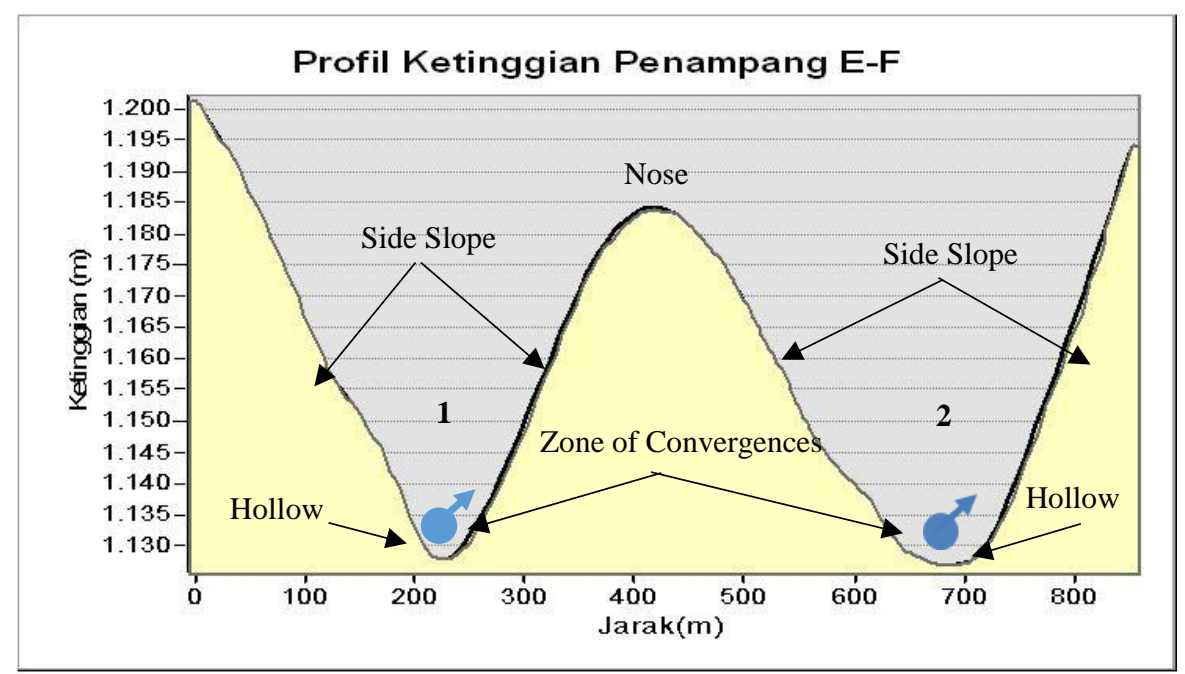

8c. Profil Ketinggian Penampang DAS Orde 0 ( Nol) melewati Kelompok Mata air 1 dan 2 Gambar 8. Penampang Melintang DAS Orde 0 (Nol) Dusun Brau 
Jurnal Pendidikan Geografi:

Kajian, Teori, dan Praktik dalam Bidang Pendidikan dan Ilmu Geografi

Tahun 24, Nomor 2, Jun 2019, Hal 73-84

Sistem hollow memiliki aliran air permukaan dalam jumlah sedikit, sehingga aliran bersifat temporal atau intermitten. Meskipun begitu hollow tetap mempunyai peran penting dalam pembentukan air tanah pada suatu sistem jaringan sungai atau DAS. Pembentukan aliran air permukaan hanya ada pada saat musim hujan (Meyer, et al., 2007). Rembesan (seepage) dan mata air (spring) yang keluar dari hollow, berasal dari aliran dasar air tanah keluar ke permukaan tanah (Gambar 9 dan 10). Cekungan-cekungan kecil di lereng miring menjadi tempat akumulasinya aliran dasar air tanah yang merembes dari pori-pori batuan. Selanjutnya, air tanah yang merembes akan menggenang dan mengalir ke parit dangkal hasil erosi di bagian sisi terendah dari cekungan. Penduduk Dusun Brau memanfaatkan air yang mengalir keluar dari genangan tersebut sebagai sumber air baku utama untuk memenuhi kebutuhan air kegiatan domestik, pengairan, dan irigasi pertanian. Penyaluran air dilakukan melalui pipa-pipa kecil yang kemudian didistribusikan ke semua penduduk. Debit mata air yang keluar sebesar 11,53 ml/detik dan 54,20 ml/detik (lihat Gambar 11 dan 12).

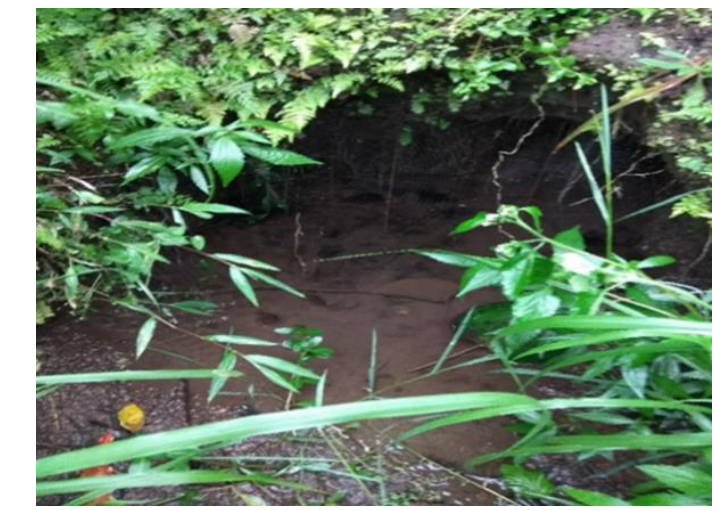

Gambar 9. Rembesan aliran dasar pada lereng yang curam (koordinat: 664977 mT, 9131947 mU, 1125 mdpl, lereng $>45^{\circ}$ )

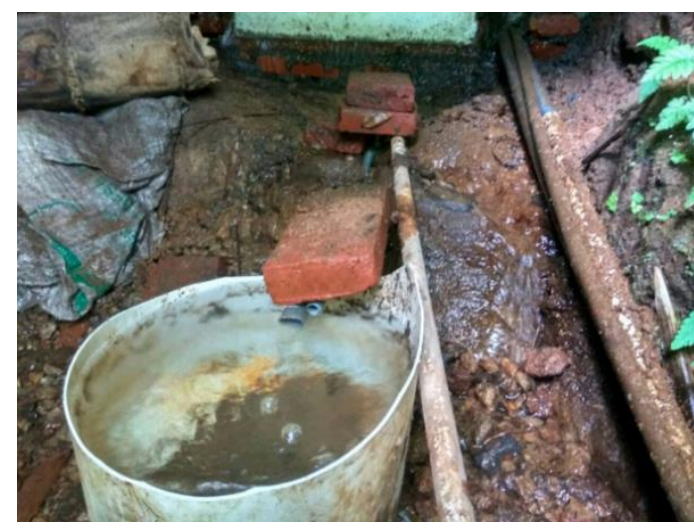

Gambar 11. Mata air pada lereng yang curam (koordinat: $665403 \mathrm{mT}, 9131911 \mathrm{mU}, 1174 \mathrm{mdpl}$, lereng $>45^{\circ}$ )

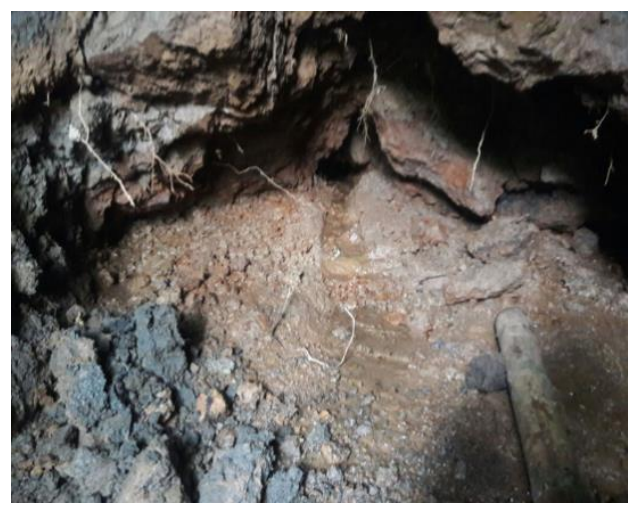

Gambar 10. Rembesan aliran dasar pada lereng yang curam (koordinat: 664977 mT, 9131947 mU, 1125 mdpl, lereng $>45^{\circ}$ )

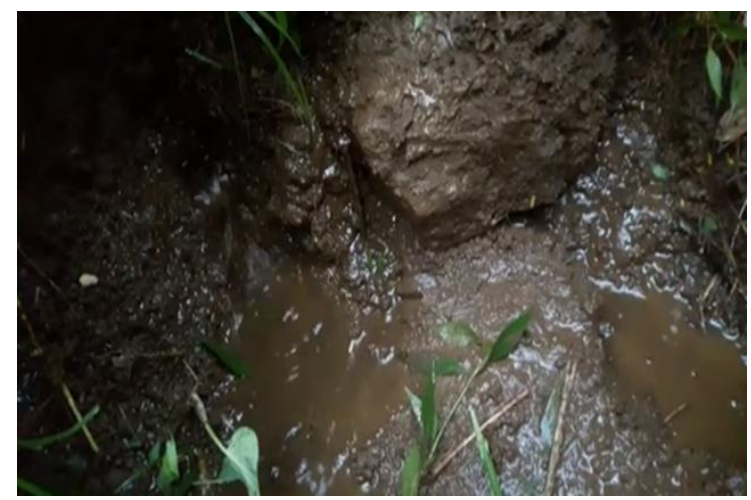

Gambar 12. Mata air pada lereng yang curam (koordinat: $664977 \mathrm{mT}, 9131911 \mathrm{mU}, 1132 \mathrm{mdpl}$, lereng >45)

DAS Orde 0 (Nol) di Dusun Brau, berada di lereng curam. Berdasarkan kajian hidrogeomorfologi, daerah ini berupa medan bergunung dan mempunyai aktivitas gerak massa intensif berupa longsor. Tingginya kejadian longsor, menyebabkan erosi parit justru tidak nampak. Gambar 9 dan 10 menunjukkan lingkungan pengendapan material debris di sekitar rembesan dan mata air. Lingkungan pengendapan material ini memberikan dampak besar terhadap pembentukan air tanah. Air tanah yang terakumulasi di daerah pengendapan 
Jurnal Pendidikan Geografi:

Kajian, Teori, dan Praktik dalam Bidang Pendidikan dan Ilmu Geografi

Tahun 24, Nomor 2, Jun 2019, Hal 73-84

dan mengalir ke daerah tekuk lereng akan keluar sebagai rembesan dan mata air, sebagian di antaranya berupa zona depresi yang sempit (Lihat Gambar 9 dan 10).

DAS Orde 0 (Nol) di Dusun Brau memiliki bentukan morfologi curam serta medan bergunung. Pada Tabel 1 ditunjukkan data kondisi geomorfologi dan hidrologi DAS Orde 0 (Nol) di Dusun Brau. Kondisi pada sistem topografi Nose, Side Slope, dan Hollow (Zone of Convergence) akan menentukan kondisi hidrogeomorfologi DAS Orde 0 (Nol) (Gambar 8c). Antara kedua hollow dari kelompok mata air 1 dan 2 terdapat Nose. Nose merupakan igir yang memiliki elevasi tertinggi $1.180 \mathrm{mdpl}$. Sistem topografi Nose dan hollow membentuk lereng (Side Slope) dengan kemiringan lebih $45^{\circ}$. Proses geomorfologi berupa gerak massa (longsor) berlangsung intensif di sistem Side Slope. Pada bagian Side Slope, dapat ditemukan singkapan batuan induk. Struktur geologi pada batuan induk berupa retakan dan rekahan. Jenis batuan induk yang tersingkap yaitu tuff, breksi, dan breksi tuff. Erosi merupakan proses geomorfologi yang umum terjadi pada hollow. Pada DAS Orde 0 (Nol) di Dusun Brau, proses geomorfologi berupa erosi parit pada hollow masih belum begitu nampak jelas. Hollow dan zone of convergence masih didominasi oleh proses pengendapan sedimen yang berasal dari hasil gerak massa pada Side Slope. Sedimen pada hollow menjadikan hollow merupakan tempat yang baik bagi air untuk terinfiltrasi. Selanjutnya, air yang keluar dari hollow akan membentuk rembesan dan mata air. Rembesan dan mata air tersebut selanjutnya mengalir menjadi channel yang membentuk jaringan 2 (dua) sungai utama di Dusun Brau. Kondisi geomorfologi DAS Orde 0 (Nol) akan mempengaruhi kondisi hidrologinya. Kondisi geomorfologi DAS menjadikan proses hidrologi dominan pada Nose dan Side Slope adalah aliran permukaan yang tipis saat terjadi hujan. Porositas dan permeabilitas sedang hingga besar terjadi akibat struktur retakan dan rekahan. Hal ini menjadikan air mudah terinfiltrasi dengan baik dan mengalir secara gravitative menuruni Side Slope. Air kemudian mengalir sebagai aliran bawah permukaan pada sistem hollow. Mata air dan rembesan sebagai outlet DAS Orde 0 (Nol) akan membentuk channel yang airnya mengalir sepanjang tahun sebagi sungai Orde 1.

Tabel 1. Kondisi Geomorfologi dan Hidrologi DAS Orde 0 (Nol) Dusun Brau

\begin{tabular}{|c|c|c|c|}
\hline Parameter Kondisi & Variabel Karakteristik & & erangan \\
\hline \multirow{11}{*}{ Geomorfologi } & Jenis batuan & Tuff, Breksi, breksi tuff & $\begin{array}{l}\text { Mengalami pelapukan dan } \\
\text { perombakan intensif }\end{array}$ \\
\hline & Struktur geologi & Retakan dan rekahan & $\begin{array}{c}\text { Retakan dan rekahan banyak } \\
\text { ditemukan pada batuan induk } \\
\text { yang tersingkap di bagian lereng } \\
\text { yang curam }\end{array}$ \\
\hline & Porositas batuan & Sedang hingga tinggi & $\begin{array}{l}\text { Jenis batuan tuff dan breksi } \\
\text { dengan retakan dan pecahan }\end{array}$ \\
\hline & Permeabilitas batuan & Sedang hingga tinggi & $\begin{array}{c}\text { Batuan yang kompak mengalami } \\
\text { perombakan. }\end{array}$ \\
\hline & Kemiringan lereng & $>45^{\circ}$ & Pada system Side Slope dan Nose \\
\hline & Morfologi & Curam & Gambar 7 \\
\hline & Medan & Bergunung & Gambar 7 \\
\hline & \multirow{2}{*}{ Gerak massa } & Longsor & $\begin{array}{l}\text { Pada lereng yang curam (Side } \\
\text { Slope) }\end{array}$ \\
\hline & & Erosi parit & $\begin{array}{l}\text { Belum begitu nampak jelas pada } \\
\text { system hollow }\end{array}$ \\
\hline & \multirow[t]{2}{*}{ Pengendapan } & Aliran debris dan bongkah & $\begin{array}{c}\text { Aliran debris dari materi tuff dan } \\
\text { bongkah hasil perombakan } \\
\text { batuan induk dan breksi. }\end{array}$ \\
\hline & & Lokasi pengendapan & $\begin{array}{c}\text { Pada bagian sekitar } \\
\text { rembesan/mata air setelah } \\
\text { Hollow atau bagian hulu mata air }\end{array}$ \\
\hline
\end{tabular}


Jurnal Pendidikan Geografi:

Kajian, Teori, dan Praktik dalam Bidang Pendidikan dan Ilmu Geografi

Tahun 24, Nomor 2, Jun 2019, Hal 73-84

\begin{tabular}{|c|c|c|c|}
\hline Parameter Kondisi & Variabel Karakteristik & & erangan \\
\hline \multirow{5}{*}{ Hidrologi } & Dinamika panas & Tertutup oleh kanopi & Masuk dalam wilayah Perhutani \\
\hline & \multirow[b]{2}{*}{ Jenis Aliran Air } & $\begin{array}{c}\text { Aliran permukaan }(\text { Run } \\
\text { Off) }\end{array}$ & $\begin{array}{c}\text { Aliran permukaan tidak nampak } \\
\text { di permukaan tanah }\end{array}$ \\
\hline & & $\begin{array}{l}\text { Aliran bawah permukaan } \\
\text { (Sub Surface Runoff) }\end{array}$ & $\begin{array}{c}\text { Aliran berupa aliran dasar yang } \\
\text { muncul sebagai mata air dan } \\
\text { rembesan sebelum akhirnya } \\
\text { menjadi alur sungai. }\end{array}$ \\
\hline & \multirow{2}{*}{ Sifat aliran air } & $\begin{array}{l}\text { Aliran permukaan (Run } \\
\text { Off) }\end{array}$ & $\begin{array}{l}\text { Hanya nampak setelah terjadi } \\
\text { hujan }\end{array}$ \\
\hline & & $\begin{array}{l}\text { Aliran bawah permukaan } \\
\text { (Sub Surface Runoff) }\end{array}$ & Mengalir sepanjang tahun \\
\hline
\end{tabular}

Jenis batuan terendapkan pada DAS Orde 0 (Nol) Dusun Brau berupa tuff, breksi tuff, dan breksi dengan retakan dan rekahan mempunyai porositas dan permeabilitas tinggi. Todd (1980) menjelaskan bahwa porositas tuff mencapai 41\%, sedangkan porositas breksi tinggi sangat bergantung pada kondisi retakan dan rekahan. Kondisi ini mengindikasikan bahwa secara hidrologi, daerah ini sangat memungkinkan terbentuknya rembesan dan mata air. Fungsi utama DAS Orde 0 (Nol) di daerah ini, yaitu untuk mengakumulasikan air. Akumulasi ini dilakukan sebelum terbentuknya sistem jaringan sungai kompleks. Selain itu, kondisi hidrogeomorfologi DAS Orde 0 ( $\mathrm{Nol})$ di Dusun Brau juga sangat memungkinkan untuk terbentuknya aliran dasar yang mengalir sepanjang tahun (perennial). Kondisi ini akan sangat baik dalam upaya pemenuhan air bagi berbagai aktivitas penduduk di Dusun Brau.

\section{KESIMPULAN}

Kondisi geomorfologi DAS Orde 0 (Nol) terbagi atas sistem Nose, Side Slope, Zone of Convergence, Hollow dan Channel dapat ditinjau secara detil dengan memanfataakan gambaran penampang melintang (profil) yang dibuat berdasarkan peta kontur. Identifikasi awal pada DAS Orde 0 ( Nol) dilakukan melalui observasi dan pengamatan pada kondisi lereng miring hingga curam (Side Slope). Puncak igir Side Slope akan membentuk Nose. Air dan sedimen yang berasal dari Nose dan Side Slope akan mengendap di Zone of Convergence. Sedimen akan terendapkan dalam bentuk debris, sedangkan air akan terinfiltrasi di sistem hollow. Daerah outlet dari hollow pada DAS Orde 0 ( Nol) yaitu sistem channel yang akan membentuk sungai orde 1 . Sistem channel ini dapat diketahui di lapangan dengan adanya mata air dan rembesan pada daerah tekuk lereng. Hasil identifikasi tentang karakteristik karakteristik DAS Orde 0 ( Nol) yang mencakup kondisi geomorfologi dan hidrologi dapat dimanfaatkan sebagai salah satu faktor dalam menentukkan karakteristik Orde Sungai selanjutnya.

\section{DAFTAR RUJUKAN}

Benda, L., Hassan, M. A., Church, M., \& May, a. C. (2005). Geomorphology of steepland headwaters: the transition from hillslopes to channels. Journal Of The American Water Resources Association, Paper No. 04071, 835-851.

De Wiest, a. D. (1966). Hidrogeology. Canada: John Wiley and Sons.

Dietrich, W., Reneau, S., \& Wilson, C. (1987). Overview: "zero-order basins" and problems of drainage density, sediment transport and hillslope morphology. Erosion and Sedimentation in the Pacific Rim (Proceedings of the Corvallis Symposium. Publ . no 165. IAHS Proceeding.

Gomi, T., Sidle, R. C., \& Richardson, J. S. (2002). Understanding processes and downstream linkages of headwater systems: headwaters differ from downstream reaches by their close coupling to hillslope processes, more temporal and spatial variation, and their 
Jurnal Pendidikan Geografi:

Kajian, Teori, dan Praktik dalam Bidang Pendidikan dan Ilmu Geografi

Tahun 24, Nomor 2, Jun 2019, Hal 73-84

need for different means of protection from land. Journal of BioScience, 52(10), 905916.

Grieve, S. W., Hales, T. C., Parker, R. N., Mudd, S. M., \& Clubb, F. J. (2018). Controls on zero-order basin morphology. Journal of Geophysical Research: Earth Surface, 123, 3269-3291. doi:https://doi.org/10.1029/2017JF004453

Hendrayana, H. (2015). Hidrogeologi Mata Air.

Meyer, J. L., Kaplan, L. A., Newbold, D., David L. Strayer, C. J., Zedler, J. B., Beilfuss, R., Zedler, P. H. (2007). Where rivers are born: The Scientific imperative for defending small streams and wetlands. (M. N. Jensen, \& D. Sutton, Penyunt.) Sierra Club Foundation, The Turner Foundation and American Rivers.

Morse, M. S., Ning Lu, F. A., Godt, J. W., Revil, A., \& Coe, a. J. (2012). Comparison of soil thickness in a zero-order basin in the Oregon Coast Range using a soil probe and electrical resistivity tomography. Journal Of Geotechnical and Geoenvironmental Engineering, Vol. 138, No. 12, 470-1482.

Munir, H. M. (1995). Geologi dan mineralogi tanah. Malang.

Santosa, S., \& Suwarti, T. (1992). Geologi lembar Malang, Jawa. . Bandung: Pusat Penelitian dan Pengembangan Geologi .

Sidle, R. (2018, July). Discovery of zero-order basins as an important link for progress in Hydrogeomorphology. Dalam Hydrological Processes (hal. 3059-3065). John Wiley \& Son.

Todd, D. (1980). Groundwater hidrology ( 2nd edition ed.). New York: John Wiley and Sons.

Triatmojo, B. (2008). Aplikasi hidrologi. Yogyakarta: Beta Offset.

Tsukamoto, Y., \& Hirohiko, M. (1987). Hydrogeomorphological characteristics of a zeroorder basin. Proceedings of the Corvallis Symposium. IAHS Vol. Pubi. no. 165. IAHS Proceeding.

Verstappen. (1983). Applied geomorfologi : Geomorphological surveys for environtmental development. The Netherland: Elsevier.

Yamada, S. (1999). The role of soil creep and slope failure in the landscape evolution of a head water basin: field measurements in a zero order basin of northern Japan. Journal of Geomorphology, 28, 329-344. 